\title{
Correction to: The Histopathology of Severe Graded Compression in Lower Thoracic Spinal Cord Segment of Rat, Evaluated at Late Post-injury Phase
}

\author{
Jana Fedorova $^{1}$ (D) Erika Kellerova ${ }^{1}$ D $\cdot$ Katarina Bimbova $^{1}$ (D) Jaroslav Pavel $^{1}(\mathbb{D}$
}

Published online: 17 September 2021

(c) The Author(s) 2021

\section{Correction to: Cellular and Molecular Neurobiology https://doi.org/10.1007/s10571-021-01139-7}

The original version of this article unfortunately contained error in author group.

The given name and family name of all the authors was swapped and published incorrectly. Now, the correct author names are presented in this correction article.

The original article has been corrected.

Open Access This article is licensed under a Creative Commons Attribution 4.0 International License, which permits use, sharing, adaptation, distribution and reproduction in any medium or format, as long as you give appropriate credit to the original author(s) and the source, provide a link to the Creative Commons licence, and indicate if changes were made. The images or other third party material in this article are included in the article's Creative Commons licence, unless indicated otherwise in a credit line to the material. If material is not included in the article's Creative Commons licence and your intended use is not permitted by statutory regulation or exceeds the permitted use, you will need to obtain permission directly from the copyright holder. To view a copy of this licence, visit http://creativecommons. org/licenses/by/4.0/.

Publisher's Note Springer Nature remains neutral with regard to jurisdictional claims in published maps and institutional affiliations.
The original article can be found online at https://doi.org/10.1007/ s10571-021-01139-7.

Jaroslav Pavel pavel@ saske.sk

1 Department of Neurodegeneration, Plasticity and Repair, Institute of Neurobiology, Biomedical Research Center of the Slovak Academy of Sciences, Soltesovej 4-6, 04001 Kosice, Slovakia 